"Accentuating criminal sanctions for environmental degradation: issues and perspectives"

\begin{tabular}{|c|c|c|}
\hline AUTHORS & $\begin{array}{l}\text { Kola O. Odeku } \\
\text { Simbarashe R. Gundani }\end{array}$ & \\
\hline ARTICLE INFO & $\begin{array}{l}\text { Kola O. Odeku and Simbarashe } \\
\text { sanctions for environmental deg } \\
\text { Environmental Economics, } 8(2)\end{array}$ & $\begin{array}{l}\text { Accentuating criminal } \\
\text { d perspectives. } \\
11 / \text { ee.08(2).2017.03 }\end{array}$ \\
\hline DOI & http://dx.doi.org/10.21511/ee.08 & \\
\hline RELEASED ON & Friday, 09 June 2017 & \\
\hline RECEIVED ON & Tuesday, 04 April 2017 & \\
\hline ACCEPTED ON & Monday, 22 May 2017 & \\
\hline LICENSE & $\begin{array}{l}(c) E Y \\
\text { This work is licensed under a C } \\
\text { License }\end{array}$ & Attribution 4.0 International \\
\hline JOURNAL & "Environmental Economics" & \\
\hline ISSN PRINT & $1998-6041$ & \\
\hline ISSN ONLINE & $1998-605 X$ & \\
\hline PUBLISHER & LLC "Consulting Publishing Cor & erspectives" \\
\hline FOUNDER & LLC "Consulting Publishing Cor & erspectives" \\
\hline$\sigma^{\circ}$ & 15 & ニ:こ \\
\hline NUMBER OF REFERENCES & NUMBER OF FIGURES & NUMBER OF TABLES \\
\hline 48 & 0 & 0 \\
\hline
\end{tabular}

(c) The author(s) 2022. This publication is an open access article. 
Kola O. Odeku (South Africa), Simbarashe R. Gundani (South Africa)

\title{
Accentuating criminal sanctions for environmental degradation: issues and perspectives
}

\begin{abstract}
This article examines the need to enforce criminal sanctions for environmental crimes being perpetrated daily, particularly by those who engage in mining and extractive ventures. In South Africa, more often than not, the sanctions for environmental crimes are usually premised on civil suits or administrative actions against the perpetrators. However, these sanctions have not been effective in dissuading perpetrators from environmental harm and degradation because they have the financial means to settle any claims or fines imposed by the courts or the administrative tribunals. It is against the backdrop of this culture of deliberate impunity that this article accentuates the need to strengthen sanctions against perpetrators by imposing criminal sanctions in order to serve as deterrent. A precedent was set by the court in the case of Blue Platinum Ventures (Pty) Limited and Maponya, where the court emphatically invoked and applied criminal sanction against the defendant and was held criminally liable for degrading the environment. The case is a landmark, as it sets a new precedent, where the perpetrator was criminally sanctioned. Countries like United States of America and Australia have been successful in criminal sanctioning of environmental crimes; many mining and extractives companies' executives and managers have been criminally sanctioned and sent to jail. This article looks at the jurisprudence from these jurisdictions and draws useful lessons that could be used to strengthen prosecution and conviction of perpetrators in South Africa.
\end{abstract}

Keywords: extractive industry, environmental harm and degradation, environmental crimes, criminal sanctions, perpetrators.

JEL Classification: N57, K14, O13.

Received on: $4^{\text {th }}$ of April, 2017.

Accepted on: $22^{\text {rd }}$ of May, 2017.

\section{Introduction}

Criminal sanctions for environmental crimes are novel in South Africa (Glazewski and Witbooi, 2002). Most times, when the environment has been harmed and degraded, civil and administrative remedies were sought and used to make perpetrators accountable (White, 2013). An important legislation which was enacted to combat environmental harm and degradation is the National Environmental Management Act 107 of 1998 (NEMA). NEMA has been recently amended, and the amendment contains numerous provisions for imposing sanctions and civil liabilities on the directors, managers and officials of companies who pollute, harm and degrade the environment. South Africa has now chosen to employ its ultimate legal weapon-criminal law against environmental offenders in order to deter the misbehavior and more crucially to protect the environment and public health. Therefore, the people who are entrusted with

(c) Kola O. Odeku, Simbarashe R. Gundani, 2017.

Kola O. Odeku, Faculty of Management and Law, School of Law, Department of Public and Environmental Law, University of Limpopo, South Africa.

Simbarashe R. Gundani, Faculty of Management and Law, School of Law, Department of Public and Environmental Law, University of Limpopo, South Africa.

This is an Open Access article, distributed under the terms of the Creative Commons Attribution 4.0 International license, which permits unrestricted re-use, distribution, and reproduction in any medium, provided the original work is properly cited. protecting the environment must take responsibility and do the right thing by enforcing the law (Lazarus, 1995). The preamble to NEMA explicitly supports this approach and it enjoins the state to facilitate the enforcement of environmental laws wherever and whenever they have been breached.

It is trite that environmental law and criminal sanctions are two distinct bodies of laws, however, the case of Blue Platinum Ventures (Pty) Ltd, RN126/13 in South Africa has brought about an integration of the two and has shown that criminal sanctions for environmental infraction can be imposed by a competent court. Enforcement of environmental law is very imperative considering how environmental culprits perpetrate degradation and other vices with impunity (Wolff, 2016). It is against the backdrop of this that the three arms of government ,namely national, provincial and local, should cooperate and strengthen the enforcement of environmental law and invoke salient provisions that seek to criminalize environmental misbehaviors, whenever and wherever they occur (Blomquist, 2011).

In South Africa, fines are usually imposed by the court and the administrative bodies whenever environmental crimes are committed; prison term is rarely imposed (Sachs, 1996). Most times, the perpetrators go scot-free because of lack of technically skilled personnel to prosecute this specialized crime. Consequently, the level of degradation and pollution keep escalating because 
enforcement of the existing laws is very weak. This is promoting culture of impunity. In order to effectively deter and totally eradicate environmental degradation, stiffer measures such as criminal sanctions must be stringently enforced against the offenders.

This article seeks to enlighten on desirability of applying criminal sanctions as enshrined in the Criminal Procedure Act 51 of 1977 (hereafter referred to as CPA) and other legislation that have been introduced to deter and curb environmental crimes in South Africa. More importantly, the recent amendment to the NEMA is apt because it contains stringent provisions that can be used to strengthen enforcement of criminal sanctions for environmental crimes. South Africa is not the only country that is seeking to combat environmental harm and degradation; other countries are also actively doing the same, particularly in developed countries such as the United States of America and Australia. This article examines salient parts of their laws that prohibit environmental degradation and prescribe criminal sanctions for transgressions. Lessons drawn from these jurisdictions were used to discuss how South Africa can make its own enforcement more effective and efficient in order to deter environmental misbehaviors and combat culture of impunity. More importantly, the bold stance taken by the court in the case of Blue Platinum Ventures to convict and sentence the accused for degrading the environment by carrying out extractive activities without proper authorization was appraised.

\section{Theoretical background}

In South Africa, criminal sanctions relate to the application of the CPA to crimes committed and the prosecution of the crimes in a court of law wherein a conviction is made and a sentence imposed. Relating this to environmental crimes would mean subjecting individuals who harm the environment to be tried in a criminal court and be punished, so as to deter future culprits. Criminal sanctions provide a last resort in both practical and symbolic terms for dealing with recalcitrant environmental culprits (Rankin \& Finkle, 1983). Criminal sanctions also operate in such schemes as to punish the behaviors of those who do not carry out all or part of their activities within the approved scheme (Scott, 2004). It also discourages environmental degrader companies from continuing to perpetrate harming and degrading the environment with impunity knowing full well that there is possibility of imposing stringent sanction against them and their officials for transgressing the law (Rabie, 1972). It is, therefore, pertinent to point out that there are many approaches to addressing environmental harm and degradation that do not honor the legal limitations, one of them is through criminal law (Wolff, 2016).

It is against the backdrop of this that environmental crimes in South Africa may be described as conducts that are in violation of the CPA and particularly, section 24 of the Constitution of the Republic of South Africa, 1996. This section is popularly known as the environmental clause and prohibits perpetration, harming or degrading of the environment, ecosystems and human health. NEMA was promulgated to give effect to the realization of section 24 and, as such, it contains both civil and criminal provisions sanctioning the harming and degradation of the environment. Environmental crime is defined as "an act committed with intent to harm or with a potential to cause harm to ecological and/or biological systems and for securing business or personal advantage" (White, 2013). It is also considered "as an act that violates an environmental protection statute" (Clifford, 1998). Therefore, the concept of enforcement and sanctioning of environmental crimes should be understood in terms of "the range of procedures and actions employed by a State, its competent authorities and agencies to ensure that organizations or persons, potentially failing to comply with environmental laws or regulations, can be brought or returned into compliance and/or punished through civil, administrative or criminal actions" (Hodas, 1995).

More importantly, NEMA imposes a general duty on all persons to take reasonable measures to avoid, or to minimize and rectify, significant harm caused to the environment (Soltau, 1999). The authorities have the powers to criminally prosecute perpetrators in terms of section 28(14). This section provides that if a person is found to have transgressed the provisions of the law, the person is liable to pay a fine of a million rand, alternatively the person could be sentenced to imprisonment for a year or given a combination of both. More importantly section 34 of NEMA as amended extends the scope of both civil and criminal responsibilities to include firms (companies and partnerships) and their directors (including board members, executive committees) to be held accountable in their personal capacities for crimes committed against the environment. Liability also extends to managers, agents, or employees who deliberately fail to perform an allocated task, while acting on the employer's instructions. In such circumstances, the offence must be listed under schedule 3 of section 28(14) of NEMA and the person concerned must have failed to take all reasonable steps to avert the harm or commission of the offense considering his or her personal 
circumstances. More importantly, since section 28(14) is now listed as a Schedule 3 offence. This means that unless it can be shown that all reasonable steps necessary to prevent the crime were taken, even an unintentional (but negligent) unlawful act or omission which causes significant harm or degradation of the environment can make a director personally liable.

The environment is a common heritage, it belongs to all living and non-living things (Littledyke, 2008). Its protection is universal and the international community has been very proactive in rolling out and implementing numerous international instruments to ensure that the environment is protected and sustained for current and future generations.

Intentional or inadvertent harming of the environment is a serious crime, which must be sanctioned (Anthony, 2006). Environmental crimes differ considerably from the traditional criminal model that focuses on crimes against persons and private properties (Crowe, 2000). Because of the unique nature of environmental crimes, its prosecution usually poses a huge challenge. Notwithstanding, there have been successful stories, where perpetrators have been prosecuted and jailed for environmental crimes. The crime is now universally regarded as a unique category of crime that should be prosecuted and perpetrators convicted and sentenced accordingly (Packer, 1968).

\section{Literature review}

The application of criminal sanctions to environmental crimes is essential considering that "environmental crime encompasses a wide range of activities and behaviors that produce environmental harm. These activities range from careless behavior to those of a more deliberate nature" (Samantha, 2010). Therefore, as part of the strategy to deter the culture of degradation with impunity, stringent application of criminal laws is advocated as one of the sanctions that should be frequently imposed whenever the environment is harmed or degraded. Environmental crime is not localized, rather, it is a global problem (Wolff, 2016). Nowadays, many countries have resorted to imposing criminal sanctions to ensure compliance (Situ \& Emmons, 1999). Bellamy (2003) pointed out that "industries in the United States are heavily regulated, especially in pollution control. When monetary fines imposed for violations of pollution control laws became a mere 'cost of doing businesses, criminal sanctions for executives and managers who violate these laws were added to the American regulatory scheme". This shows that in the USA, the government is keen on maintaining a clean environment to the extent of imposing criminal sanctions against erring perpetrators. This approach should be emulated in South Africa in view of the recent persistent degradation of the environment by corporate bodies and individuals.

It is our candid opinion that "imprisonment, one of the most severe methods of punishment, is a suitable option to repress and prevent environmental crimes" (Wolff, 2016). Pursuant to this, the court's decision in the case of State vs Blue Platinum Ventures Pty Ltd, where the offender was convicted for harming and degrading the environment is a step in the right direction. One of the notable pronouncements in the judgment is when it was categorically stated that it was upon the court to see to it that an appropriate sentence must be one that will benefit the community and at the same time deter the accused from committing the same offence. This approach ensured that such crimes are kept to a minimum or are eradicated completely.

It is apparent that to be lenient with offenders for environmental crimes will only result in more cases of degradation and pollution which will promote and encourage culture of impunity (Uhlmann, 2009). It is pertinent to point out that the present measures such as the polluter pays principle and precautionary measure currently being pursued for sanctioning environmental crimes are failing dismally to curb the occurrence of environmental harm and degradation because the perpetrators usually have the financial means to settle the claims and fines. It is against the backdrop of the weakness and ineffectiveness of these measures, that Howard (1991) indicated that the recent environmental disasters in different countries have triggered public attention on the need to effectively implement and enforce environmental laws that are in place to sanction degradation and harm to the environment. It is, therefore, critically imperative that the environmental law enforcers should focus on the criminal enforcement of the major environmental laws to deter such destructive behaviors. Criminal sanction combined with the application and enforcement of other environmental strategies and measures would be effective and efficient mechanisms to strengthen enforcement and deter polluters and degraders. Furthermore, in support of criminal sanctions, it seems apparent that the approach of imposing fines is proving to be ineffective to deter environmental misbehaviors (Bucy, 1990). Therefore, punitive sanction such as criminal sanction becomes inevitable if environmental harm and degradation is to be curtailed (Larkin, 2014). 
There are various challenges that are impeding accountability for environmental harm and degradation such as underutilization of criminal sanctions under environmental statutes, practices, such as issuing permits and licences for exploration and prospecting without prior environmental assessment impacts and difficulties involved in the prosecution of corporate offenders (Allan, 1987). To combat this, there is need for increased prosecution and harsher sentencing of both corporations and corporate managers (Allan, 1987). This approach is recommendable as it would reduce the number of environmental related crimes and serve as an effective deterrence against perpetrators who ordinarily would be afraid of the imminent stigma of the likelihood of being convicted and sentenced to jail.

Pain (1993) pointed out that in Australia, criminal law has always had a place in the environmental protection regimes. She asserts that there is need to sharply increase criminal penalties and the scope of criminal offences in relation to the environment, and to tip the scale in favor of what is seen as coercion rather than the encouragement of compliance (Pain, 1993). This means that perpetrators can be forced to comply with environmental laws rather than encouraging compliance (Weiss \& Jacobson, 2000). Such coercion is done through criminal sanctions imposed for environmental crimes (Green et al., 2007).

\section{Criminal sanctions for environmental crimes: an examination of the case of State vs Blue Platinum Ventures and Maponya}

In South Africa, the court has recently applied and enforced criminal sanctions to environmental crimes in the recent case of Blue Platinum Ventures. This is a landmark case that will be distilled in order to synthesize how the court considered and applied the law where both perpetrators were held criminally liable. The judgement in this case stresses the seriousness of law-makers and the government in protecting the environment from constant harm and degradation especially by individuals and companies.

3.1. The facts of the case. The Blue Platinum Ventures case was about severe soil erosion that was caused by a newly formed company called Blue Platinum Ventures which was digging clay to mould bricks. The company was owned by Mr Matome Samuel Maponya, who was the co-accused in the case. The court charged both the company and the owner for commencing with an activity under 1(e) of Listing Notice 2 of 2006 which states that: "the construction of facilities or infrastructure, including associated structures or infrastructure, for any process or activity which requires a permit or licence in terms of legislation governing the generation or release of emissions, pollutions, effluent or waste which has not been identified in Listing notice 1 of 2006 without first obtaining the necessary environmental authorization as is obliged to do in terms of Section 24 of NEMA".

The activity entailed the clearing of vegetation and excavation of large holes and pits, which caused large scale soil erosion and other serious harm to the surrounding environment including the health and safety of the neighboring village and its livestock. This activity led a concerned community member to approach the Police Station to lay charges against the company for the alleged contraventions of NEMA. The Police took the matter up and notified the Inspectorate, and a joint investigation team was formed between the Department of Environmental Affairs (DEA) and the Limpopo Commercial Crime Unit.

The company was formerly charged in terms of NEMA, and subsequently, the owner of the company was also charged in terms of section 34 of NEMA in his personal capacity for failing to take all reasonable steps that were necessary in the circumstances to prevent the damage caused by his company to the environment. This was specifically in reference to the fact that the company had no environmental authorization to carry out the activities in question. Evidence was presented that he had failed to provide the experts with all the documentation needed to process the applications needed to carry out the activities. Mr Maponya pleaded guilty to this charge in the Lenyenye Magistrates Court in Limpopo, South Africa. The accused entered into a plea deal wherein they pleaded guilty in terms of section 112 of the CPA.

3.2. Judgement of the court. The accused was sentenced to five years imprisonment which was wholly suspended for a period of five years on condition that the accused is not convicted again of contravening the provisions of section $24(\mathrm{~F})(1)$ of NEMA during the period of suspension. The sentence was passed on condition that the accused rehabilitates all the areas which were damaged by his company's mining activities.

3.3. The significance of the judgement. The judgement showed that the court is in a position to enforce section 34 of NEMA and sentence individuals who caused harm and degradation to the environment. It is pertinent to point out that when it comes to punishable misbehaviors, criminal sanctions could serve as more effective deterrent for 
offenders than civil actions (Coffee, 1980). In the judgement, by criminally convicting the accused persons, even though the sentence was suspended, the owner of the company already has a criminal record which would have a huge impact on him personally and his business. It also serves as a deterrent to would-be perpetrators that the court will not hesitate to criminally sanction environmental crimes committed by an individual or a corporate entity. The judgement emboldens other authorities and courts to take a strong stand against environmental crimes and punish perpetrators.

The fact that the court also extends liability to the directors and managers of the company is also remarkable because the offenders were prevented from hiding behind the protection of the company while continuously harming the environment. The judgement also stresses the importance of obtaining authorizations for all activities that will impact the environment prior, during and after mining. Relying on the court's decision, it is apparent that failure to obtain such authorizations could lead to criminal prosecution and conviction.

In addition to the criminal sanction, the court also imposed civil remedy to rehabilitate the damaged areas. This is a productive sanction as it compelled the perpetrators to repair the damage done to the environment. The impact of this judgement in holding the perpetrators accountable is remarkable in the sense that the accused was sentenced and ordered to rehabilitate the environment. This is a more effective deterrent against recalcitrant offenders in order to deter and curb culture of impunity.

\section{Challenges in using criminal laws to prosecute environmental crimes}

While the use of criminal sanctions against perpetrators of environmental crimes seems to be the most potent tool to deter impunity (Cable \& Benson, 1993), some scholars have argued that imposing criminal sanctions for environmental crimes is exaggerated and would result in what may be called over criminalization (Munro \& Husak, 2009). To this end, Blomquist states that applying criminal law to environmental crimes will result in an extensive use of substantive criminal law and the unreasonable use of punishment. We are quick to point out that this argument does not consider the irreversible and irreparable damages being inflicted on the environment and the health of the people and the ecosystems. Therefore, it is reiterated that while other sanctions should be effectively used to reverse and deter environmental misbehaviors, criminal sanctions should play important role and be vigorously used since it may be the only form of deterrence that would work effectively to reduce environmental damage in South Africa.

Other scholars have argued that the application of criminal law to environmental cases would also create some problems since criminal law has certain requirements by law such as the issue of intention or mens rea that have to be proved to enable a conviction. Mustafa and Muhamed (2015) indicated that there are various factors that must be considered in an environmental offence, such as what the harm was done, whether the action caused immediate harm or was only potentially harmful; and who the offender is. Therefore, all these elements must be proved in the court in order to secure a conviction (Godsil, 1991), unless such harm relates to certain individuals, who have suffered as a result of the action (Lazarus \& Cohen, 1997). While this argument sounds good, it does not preclude the application and the enforcement of criminal sanctions as prescribed in the environmental statutes. What is required is for the criminal justice system to ensure that there are skilled and well equipped prosecutors that will present credible evidence based on experts witnesses in order to prove intention and all other criminal elements required to secure conviction.

It is therefore important to point out that the introduction of criminal law to environmental crimes places an extra burden upon environmental officers to revise the strategies and manner in which they conduct investigations (Maguire \& Newburn, 2003). This revision is however complex considering the test and standard that must be met in order for the enforcement agencies to effectively and efficiently enforce the protection of the environment. The fact is that criminal law requires careful investigations and collection of evidence that meet the requirement of basic criminal law principles, such as existence of intention or mens rea to allow prosecution of such matters in a court of law (Hall, 2010). Defining the scope of environmental crime can also be confusing. Scientific uncertainties make it more difficult to prove whether an action is harmful or potentially harmful (Kriebel et al., 2001). There are also possible issues with regard to prosecution and penalties, when the offence is committed by companies. This area of environmental criminal law still requires more research to avert difficulties, when adjudicating on such cases in court, particularly in developing countries, where there is paucity of skills to prosecute, whereas developed countries like the USA and Australia have reliable skilled environmentalists, prosecutors and expert 
witnesses who are equipped to provide credible evidences that will support intent and hold perpetrators accountable. South Africa should learn from these countries. Recently, South Africa has demonstrated the willingness to go the extra mile by using available legal resources to prove a case against offenders as demonstrated in Blue Platinum Ventures case. This approach should be sustained as the end goal is to ensure that the culture of impunity is abated henceforth.

4.1. Criminal law is not preventative. It has also been observed that criminal law is not preventative by nature; it is mainly concerned with the punishment of unacceptable behavior (Clarke, 1997). It does not, therefore, prevent the occurrence of environmental harm which should be the fundamental basis of environmental protection regimes. The adversarial nature of criminal law also brings about a challenge because disputes settled in court take up time, available resources and delay the remediation of the harm, for which liability is being debated. Litigation, moreover, absorbs resources that may be more valuably directed towards remediating damage (Pain, 1993). However, criminal law is potent in cubing culture of impunity. A convicted degrader would not want to repeat the misbehavior. Moreover, conviction and sentencing will send signal to would-be offenders that harming and degrading the environment could land them in jail, destroy them and tarnish their reputations.

4.2. Nature of crimes committed unclear. The scope and nature of crimes committed against the environment is often uncertain and is not clearly defined. In criminal law there must be clarity. Certain questions must be answered. For instance, what acts constitute harm to the environment? What should be the burden of proof and on whom should it lie? These questions constitute a criminal case, and also the mens rea element must be proven to assess the state of mind of the offender. According to Farrier (1992) writing about criminal sanctions in Canada, he noted that "there are vast numbers of old environmental offences, which reflect the earlier legislative approach of maintaining silence on the issue, leaving the courts with the ostensible task of discovering Parliamentary intention". In solving this problem, courts may refer to the jurisprudence from other countries that have strong legislation and successful prosecution of environmental crimes. The legislature should also work on legislation that will pave the way for swift prosecution, where intent and other criminal elements would be easier to prove in cases involving environmental crimes.
4.3. Restriction of third parties. Criminal law also has a challenge in the sense that it does not allow third parties to bring matters to court, as they lack the standing to initiate such proceedings. This limits the applicability of criminal law, to safeguard the environment. This is inconsistent with the current norm of environmental law which allows any interested party to approach the court in cases wherein the environment is being endangered. The criminalization and enforcement of environmental crimes are evolving. In the case of State vs Blue Platinum Ventures and Maponya, it was a concerned community member who approached the Police Station to lay charges against the company for the alleged contraventions. The court assumed jurisdiction and responsibility when it heard the case and convicted the offenders according to the criminal laws in the environmental statutes.

\section{Addressing the challenges: lessons from other jurisdictions}

Even though it has been observed that there could be some challenges utilizing criminal laws to prosecute environmental crimes, these challenges can be dealt with and surmounted by drawing and learning lessons from other countries that are well equipped to prosecute and obtain convictions for environmental crimes. Against this backdrop, South Africa can draw lessons from the approaches and models being used in countries such as the United States of America and Australia. These countries are highly developed and have a lot of mining and extractive businesses spread all over the landscape of the countries. Considering the impact and the consequences of these businesses, they have put in place strong regulatory framework that contains provisions for criminal sanctions aimed at holding environmental culprits criminally liable in addition to civil liability. More importantly, these countries have well established experts and expertise that have robust knowledge of what constitute environmental crime and how to gather evidence for prosecution and conviction. The courts are also well equipped to adjudicate and preside over these types of specialized crimes.

5.1. The United States of America. The USA is one of the leading countries in the world that applies criminal sanctions to environmental crimes (Bellamy, 2002). The reason for this is that in the USA, there has been increased political pressure and public awareness that has resulted in vigorous prosecution of such crimes (Morgan, 1991). The approach has been successful in deterring perpetrators from violating the environment with impunity to the extent that the United States Department of Justice has been achieving a ninety-five percent conviction rate for all environmental prosecutions (Aufhauser, 1990). 
In the USA, the application of criminal liability for environmental crime to corporate executives is known as the responsible corporate officer doctrine (Harig, 1992). It envisages that a corporate officer is liable for the acts of his or her employees (Stessens, 1994). Bellamy (2002) emphatically asserted that "industry in the United States is heavily regulated, especially in the area of pollution control. When monetary fines imposed for violations of pollution control laws had become a mere "cost of doing business," criminal sanctions for executives and managers who pollute on their watch were added to the American regulatory scheme". The imposition of criminal sanctions has been very effective in holding individual responsible and liable. This approach was considered and upheld in Blue Platinum Ventures and Maponya's case, where the owner of the mining company who degraded the environment was held criminally liable. It is imperative for the court to continually use this legal weapon to criminally hold perpetrators liable.

Furthermore, the USA courts came up with an approach known as the "should have known" mens rea to environmental crimes, which provides that corporate officers are expected to effectively monitor and exercise control of their operations. The approach makes convictions against corporate officers less difficult than crimes requiring specific knowledge. Initially, in the USA sentences for environmental convictions commonly involved suspended sentences, probation, and community service (Kurki, 2000). However, prosecutorial zeal, combined with strict adherence to the federal sentencing guidelines have led to higher fines and incarceration. Therefore, South Africa should emulate and apply this approach to increase the number of convictions for people found guilty of environmental crimes.

5.2. Australia. Criminal law has always been applied to enforce environmental law in all jurisdictions in Australia (Pain, 1993). Criminal law performs an ancillary and supportive function to the main purpose of the regime, which is to regulate potentially harmful activities of polluters by complex licensing and permission schemes (Pain, 1993). Sanctions are last resorts in dealing with unrepentant perpetrators as the threat of criminal sanctions acts as an effective deterrent (Farrier, 1992). In Australia, in order to ensure maximum protection of the environment, existing regulatory structures have been tightened; their standards and approved processes have been re-articulated as concrete achievable outcomes rather than vague goals (Pain, 1993).
In addition, Australia amended some of its laws to allow criminal sanctions to fully take effect. For example in New South Wales (NSW), there has been the enactment of the Environmental Offences and Penalties Act 1989 which created a new broadly defined offence of "harm to the environment" in addition to increasing fines and imprisonment terms for all existing criminal environmental offences under the many NSW Acts relating to environment protection. The Act also introduced directors' liability provisions and extended criminal liability for specific waste offences. This may also be compared to the USA "should have known" mens rea, which also extends liability to directors and corporate officials.

In terms of statistics, imposing criminal sanctions to environmental crimes has recorded significant successes in Australia. There has been evidence of a substantial rise in the number of criminal prosecutions in New South Wales following the enactment of the Environmental Offences and Penalties Act (Stein, 1992). The use of criminal sanctions has led to more convictions and decrease in the number of environmental degradation cases in Australia. Therefore, criminal sanctions have proven to be very successful in these countries.

\section{Conclusion}

The environment is a heritage for all South Africans and should be conserved and protected for the benefit of everyone and even the future generations. The environment suffers, when those who have the responsibility to protect the environment from harm and degradation engage in corrupt practices such as issuing permits and licences for exploration and prospecting without prior environmental assessment impacts. Environmental misbehaviors and crimes should be sanctioned whenever they occur. It is for this reason that the existing criminal sanctions should be imposed to deter perpetrators who violate the environment with impunity. Both administrative and civil actions are failing in their bids to stop environmental crimes from taking place because of the strong financial backing of the perpetrators, hence criminal sanctions must supplement the civil and administrative actions in combating environmental harm and degradation.

\section{Recommendations}

This article recommends that:

- The approach of holding directors, corporate managers and officials liable for the acts of their employees currently being applied in the USA and Australia should be adapted by South Africa in order to strengthen compliance and enforcement. 
- Due to gaps and challenges with regard to how criminal law is being applied to environmental crimes, there is need for clear legislation, where the salient elements of what constitute environmental crimes are articulated. This would ease the court's job, when adjudicating on such cases.

- Environmental officers should be trained and equipped with knowledge on how to investigate and collect evidence relating to environmental crimes. This will boost proper prosecution of environmental offenses.

- There should be a sustained research into environmental crimes. This is important considering the technical nature of the crimes, particularly with regard to gathering and presenting of evidence in courts. More importantly, there is need for South Africa to explore and draw useful lessons from the approaches and models of jurisdictions where there have been successful prosecutions and convictions of perpetrators.

\section{Limitations of the study and areas of further studies}

There are many ways of sanctioning environmental misbehaviors in order to deter perpetrators or culprits. This current article revisit the use of criminal sanctions to hold environmental perpetrators accountable using the courts' decisions in the recent remarkable and classical case of Blue Platinum Ventures (Pty) Limited and Maponya to accentuate the effectiveness of criminal sanctions in holding those who harm and degrade the environment criminally liable. The current article, though conceptualised by the first author, was jointly written by the first and second authors. While the focus of this study is limited to the aspect examined, further studies can broadly and extensively look at the civil, administrative and other measures as part of the accountability tools to hold perpetrators accountable.

\section{References}

1. Allan, R. H. (1987). Criminal Sanctions under Federal and State Environmental Statutes. Retrieved from http://scholarship.law.berkeley.edu/elq/vol14/iss 1/4 (Accessed on 11 ${ }^{\text {th }}$ March, 2017).

2. Anthony, O. G. (2006). Criminalization of seafarers for accidental discharge of oil: Is there justification in international law for criminal sanction for negligent or accidental pollution of the sea. Retrieved from $\mathrm{http} / /$ heinonline.org/HOL/LandingPage?handle=hein.journals/jmlc37\&div=16\&id=\&page (Accessed on $21^{\text {st }}$ January, 2017).

3. Aufhauser, D. (1990). Environmental Crimes, 1990 Annual Report, 1990 A.B.A. Statistics reported are from 1990. Retrieved from http://scholarship.law.berkeley.edu/elq/vol14/iss1/4 (Accessed on $11^{\text {th }}$ March, 2017).

4. Bellamy, J. M. (2002). Putting The Boss Behind Bars: Using Criminal Sanctions Against Executives Who Pollute-What China Could Learn From The United States. Retrieved from http://heinonline.org/HOL/LandingPage (Accessed on $22^{\text {nd }}$ November, 2016).

5. Blomquist, R. F. (2011). The Logic and Limits of Environmental Criminal Law in the Global Setting: Brazil and the United States-Comparisons, Contrasts, and Questions in Search of a Robust Theory. Retrieved from http:/heinonline.org/HOL/LandingPage?handle=hein.journals/tulev25\&div=6\&id=\&page (Accessed on $2^{\text {nd }}$ January, 2017).

6. Bucy, P. H. (1990). Corporate ethos: A standard for imposing corporate criminal liability. Retrieved from $\mathrm{http} / /$ heinonline.org/HOL/LandingPage?handle=hein.journals/mnlr75\&div=46\&id=\&page $=\left(\right.$ Accessed on $1^{\text {st }}$ April, 2017).

7. Cable, S., Benson, M. (1993). Acting locally: Environmental injustice and the emergence of grass-roots environmental organizations. Retrieved from https://academic.oup.com/socpro/article-abstract/40/4/464/1639000/Acting-LocallyEnvironmental-Injustice-and-the (Accessed on $26^{\text {th }}$ January, 2017).

8. Clarke, R. V. (1997). Situational Crime Prevention Successful Case Studies. Retrieved from http://www.popcenter.org/library/reading/pdfs/scp2_intro.pdf (Accessed on $22^{\text {nd }}$ March, 2017).

9. Clifford, M. (1998). Environmental Crime: Enforcement, Policy and Social Responsibility. Gaitherburg USA: Aspen Publishing.

10. Coffee, J. C. (1980). Making the Punishment Fit the Corporation: The Problems of Finding an Optimal Corporation Criminal Sanction. Retrieved from http://heinonline.org/HOL/LandingPage?handle=hein.journals (Accessed on $24^{\text {th }}$ March, 2017).

11. Crowe, T. D. (2000). Crime prevention through environmental design: Applications of architectural design and space management concepts. Retrieved from http://www.popcenter.org/Responses/ (Accessed on 28 $8^{\text {th }}$ March, 2017).

12. Farrier, D. (1992). In search of real criminal law in Environmental Protection and Legal Change. Ed. T. Bonyhady, The Federation Press, Sydney.

13. Godsil, R. D. (1991). Remedying environmental racism. Retrieved from http://www.jstor.org/stable/1289559 (Accessed on $2^{\text {nd }}$ October, 2016).

14. Green, P., Ward, T., \& McConnachie, K. (2007). Logging and legality: Environmental crime, civil society, and the state. Retrieved from http://www.jstor.org/stable/29768437 (Accessed on $6^{\text {th }}$ January, 2017). 
15. Hall, J. (2010). General principles of criminal law. Retrieved from https://www.questia.com/library/435579/generalprinciples-of-criminal-law (Accessed on $11^{\text {th }}$ October, 2016).

16. Harig, L. A. (1992). Ignorance Is Not Bliss: Responsible Corporate Officers Convicted of Environmental Crimes and the Federal Sentencing Guidelines. Retrieved from http://www.jstor.org/stable/1372756 (Accessed on 21 ${ }^{\text {st }}$ March, 2017).

17. Hodas, D. R. (1995). Enforcement of Environmental Law in a Triangular Federal System: Can Three Not Be a Crowd When Enforcement Authority Is Shared by the Untied States, and Their citizens. Retrieved from $\mathrm{http} / /$ heinonline.org/HOL/LandingPage?handle=hein.journals/mllr54\&div=45\&id=\&page (Accessed on $14^{\text {th }}$ February, 2017).

18. Howard, B. C. (1991). Wielding the Big Stick: Deterrence and the Criminal Enforcement of Environmental. Retrieved from http://scholarship.law.wm.edu/wmelpr/ (Accessed on $1^{\text {st }}$ March, 2017).

19. Iseman, R. H. (1972). The Criminal Responsibility of Corporate Officials for Pollution of the Environment. Retrieved from $\mathrm{http} / /$ heinonline.org/HOL/LandingPage?handle=hein.journals/albany37\&div=10\&id=\&page (Accessed on $5^{\text {th }}$ December, 2016).

20. Glazewski, J., Witbooi, E. (2002). Environmental Law. Retrieved from http://heinonline.org/HOL/LandingPage?handle (Accessed on $11^{\text {st }}$ March, 2017).

21. Kriebel, D., Tickner, J., Epstein, P., \& Lemons, J. (2001). The precautionary principle in environmental science. Retrieved from https://www.ncbi.nlm.nih.gov/pmc/articles/PMC1240435/ (Accessed on $1^{\text {st }}$ October, 2016).

22. Kurki, L. (2000). Restorative and community justice in the United States. Retrieved from http://www.journals.uchicago.edu/doi/abs/10.1086/652201 (Accessed on $14^{\text {th }}$ March, 2017).

23. Larkin, P. (2014). Funding Favored Sons and Daughters: Nonprosecution Agreements and 'Extraordinary Restitution' in Environmental Criminal Cases. Retrieved from SSRN: https://ssrn.com/abstract $=2419125$ (Accessed on $2^{\text {nd }}$ April, 2017).

24. Lazarus, R. J. (1995). Meeting the Demands of Integration in the Evolution of Environmental Law: Reforming Environmental Criminal Law. Retrieved from http://heinonline.org/HOL/Page?handle=hein.journals (Accessed on $15^{\text {th }}$ December, 2016).

25. Lazarus, R. S., \& Cohen, J. B. (1997). Environmental stress. Retrieved from https://link.springer.com/chapter/10.1007\% (Accessed on $12^{\text {nd }}$ October, 2016).

26. Littledyke, M. (2008). Science education for environmental awareness: approaches to integrating cognitive and affective domains. Retrieved from http://www.tandfonline.com/doi/abs/10.1080/13504620701843301 (Accessed on $21^{\text {st }}$ October, 2016).

27. Lott, L., Karpoff, J. M., Rankine, G. (1999). Environmental Violations, Legal Penalties, and Reputation Costs. Retrieved from http://chicagounbound.uchicago.edu/law_and_economics/195/ (Accessed on 16 ${ }^{\text {st }}$ March, 2017).

28. Maguire, M., Newburn, T. (2003). Criminal investigation and crime control. Retrieved from https://books.google.com.ua/books?id=DNb6cyzIT5oC\&pg=PA66\&lpg=PA66\&dq= (Accessed on 12 ${ }^{\text {nd }}$ October, 2016).

29. Morgan, S. M. (1991). Perils of the Profession: Responsible Corporate Officer Doctrine May Facilitate a Dramatic Increase in Criminal Prosecutions of Environmental Offenders. Retrieved from http:/heinonline.org/HOL/LandingPage?handle=hein.journals/smulr45\&div=46\&id=\&page (Accessed on $26^{\text {th }}$ March, 2017).

30. Munro, V. E., Husak, D. (2009). Overcriminalization: The Limits of the Criminal Law. Retrieved from http://www.jstor.org/stable/10.1525/nclr.2009.12.2.323?seq=1\#page_scan_tab_contents (Accessed on 2 $2^{\text {nd }}$ January, 2017).

31. Mustafa, M. \& Mahomed, N. S. (2015). The Development Of Environmental Crime And Saction In Malaysia. Retrieved from http://eujournal.org/index.php/esj/article/download/6201/5970 (Accessed on 6th January, 2017).

32. Packer, H. (1968). The limits of the criminal sanction. Retrieved from http://digitalcommons.lmu.edu/cgi/viewcontent.cgi?article=1161\&context=1lr (Accessed on 29 January, 2017).

33. Pain, N. (1993). Criminal Law And Environment Protection Overview Of Issues And Themes. Retrieved from $\mathrm{http}: / /$ scholar.google.co.za/scholar?hl=en\&q=Criminal + Law + And + Environment + Protection + Overview + Of + Issues + An $\mathrm{d}+$ Themes\&btnG=\&as_sdt=1\%2C5\&as_sdtp (Accessed on 16th November, 2016).

34. Rabie, M. A. (1972). Legal remedies for environmental protection. Retrieved from http://scholar.google.co.za/scholar?hl= (Accessed on $27^{\text {th }}$ March, 2017).

35. Rankin, M., \& Finkle, P. (1983). The enforcement of environmental law: taking the environment seriously. Retrieved from http://heinonline.org/HOL/LandingPage?handle=hein.journals/ubclr17\&div=7\&id=\&page (Accessed on $26^{\text {th }}$ February, 2017).

36. Sachs, L. K. (1996). Strict Construction of the Rule of Lenity in the Interpretation of Environmental Crimes. Retrieved from http://heinonline.org/HOL/LandingPage?handle=hein.journals/nyuev5\&div=21\&id=\&page (Accessed on $2^{\text {th }}$ February, 2017).

37. Samantha, B. (2010). Environmental crime in Australia Retrieved from http://search.informit.com.au/document (Accessed on $12^{\text {th }}$ February, 2017).

38. Scott, C. (2004). Regulation in the age of governance: The rise of the post regulatory state. Retrieved from http://irserver.ucd.ie/bitstream/handle/10197/6779/RiseOfPostRegState.pdf? sequence=2 (Accessed on 27 ${ }^{\text {th }}$ February, 2017).

39. Situ, Y., \& Emmons, D. (1999). Environmental crime: The criminal justice system's role in protecting the environment. Retrieved from http://sk.sagepub.com/books/environmental-crime (Accessed on $2^{\text {nd }}$ November, 2016). 
40. Soltau, F. (1999). The National Environmental Management Act and liability for environmental damage. Retrieved from http://journals.co.za/docserver/fulltext/sajelp/6/1/8.pdf?expires=1494414565\&id=id\&accname=guest\&checksum=62BC ADCBDA17BF895E1C633D393F436D (Accessed on $2^{\text {nd }}$ March, 2017).

41. Stein, P. (1992). A possible way forward? The experiences of the Land and Environment Court of NSW in pollution control. Criminology Australia, 3(3), 13-15.

42. Stessens, G. (1994). Corporate criminal liability: a comparative perspective. Retrieved from https://www.cambridge.org/core/journals/international-and-comparative-law-quarterly/article/corporate-criminalliability-a-comparative-perspective/FF37F4A381DC9F0C44CA4B3FB9FC34C6 (Accessed on $2^{\text {nd }}$ March, 2017).

43. Uhlmann, D. M. (2009). Environmental crime comes of age: The evolution of criminal enforcement in the environmental regulatory scheme. Retrieved from http://heinonline.org/HOL/LandingPage?handle=hein. (Accessed on $1^{\text {st }}$ February, 2010).

44. Voiculescu, A. (2009). Human Rights and the New Corporate Accountability: Learning from Recent Developments in Corporate Criminal Liability. Journal of Business Ethics, 87(2), 419-510.

45. Wagner. M. 1999. Corporate criminal liability: National and international responses. Commonwealth Law Bulletin, $25(2), 600$.

46. Weiss, E. B., \& Jacobson, E. B. (2000). Engaging countries: strengthening compliance with international environmental accords. Retrieved from https://www.abebooks.com/servlet/BookDetailsPL (Accessed on 6th November, 2016).

47. White, R. (2013). Environmental crime and problem-solving courts. Crime, law and social change, 59(3), $267-278$.

48. Wolff, R. (2016). Environmental Crimes and Imprisonment: Does Prison Work to Prevent and Punish Environmental Criminals? Retrieved from http:/digitalcommons.pace.edu (Accessed on $12^{\text {th }}$ March, 2017). 